\title{
2017 SURVEY OF INDIANA LAWYER DISCIPLINE DECISIONS
}

\author{
G. MiCHAEL WITTE*
}

\section{INTRODUCTION}

The Indiana Supreme Court issues its lawyer discipline rulings in one of three methods, of which only two have public access. Upon a finding of lawyer misconduct, the court may issue either:

- A private reprimand,

- A Published Order of Discipline, or

- A Per Curiam Opinion of Discipline

There is no published ruling for a private reprimand even though a discipline original cause of action was initiated. ${ }^{1}$ However, the chronological case summary for the cause of action is accessible to the public and does contain a Clerk's entry that the case resulted in a private reprimand. Therefore, there is no public searchable database for private reprimand results. The Disciplinary Commission does maintain internally an archive of public reprimand cases, but it is not accessible to the public.

A Published Order of Discipline usually does not contain an analysis of the law or the misconduct of the lawyer. The Order merely cites a brief factual basis, lists the ethics rule(s) violated, and imposes a sanction. A Justice may dissent to the Order. The lack of written legal analysis, as well as the nature of the declaration being an Order rather than an Opinion, leads one to question whether an Order of Discipline has any value as legal precedent.

A Per Curiam Opinion is a detailed legal analysis of particular Rules of Professional Conduct as applied to the lawyer's conduct. It can contain concurring or dissenting opinions by individual Justices. A Per Curiam Opinion is considered legal precedent for future reference. Both a Published Order of Discipline and a Per Curiam Opinion are published on the court's website, are distributed to legal publications, and are distributed to local courts and bar associations.

The discipline cases reported in this Article are the result of both Published Orders of Discipline and Per Curiam Opinions.

The Indiana Supreme Court issued three (3) Per Curiam disbarment opinions during the reporting year for this Article (October 1, 2016 to September 30, 2017). It is a customary practice of the court that a disbarment will occur via a Per Curiam opinion. An additional ten (10) Per Curiam opinions of instructional

* Executive Director, Indiana Supreme Court Disciplinary Commission; J.D., 1982, Indiana University Robert H. McKinney School of Law. The opinions expressed herein are solely those of the author and do not represent a statement of law or policy by the Indiana Supreme Court, its staff or attendant agencies or organizations. The author thanks law clerk Alexandra Keller for her research assistance and editing in the creation of this work.

1. A private reprimand can result in a published Per Curiam Opinion from the Court. In that instance, the case is captioned as In re Anonymous and the offending lawyer is shielded from identification. An In re Anonymous decision is issued when the Court believes that the actions of the lawyer and the Court's ruling have heightened instructional value to the bar at large.

http://doi.org/10.18060/4806.1217 
value were issued by the court during that time frame.

\section{THE DISBARMENTS \\ $A$. In re Donald James ${ }^{2}$}

Trust account mismanagement was the basis of Donald James's misconduct. ${ }^{3}$ Failing to cooperate with the lawyer discipline process was the downfall to his license. ${ }^{4}$ His misconduct towards clients included commingling personal funds with client funds, making unauthorized cash withdrawals from his client trust account, invading client funds, using client funds for his own personal purposes, and failing to maintain trust account records. ${ }^{5}$ These misdeeds accounted for the following Professional Conduct Rule violations:

- 1.15(a): Failing to create or maintain complete records of client trust account funds, and commingling client and attorney funds.

....

- 8.4(b): Committing a criminal act (conversion) that reflects adversely on the lawyer's honesty, trustworthiness, or fitness as a lawyer.

- 8.4(c): Engaging in conduct involving dishonesty, fraud, deceit or misrepresentation. ${ }^{6}$

Also, procedural rules for trust account management were violated. ${ }^{7}$ These are found in the Indiana Admission and Discipline Rules. The specific violations were:

- 23(29)(a)(2): Failing to create or preserve trust account records for at least five years after disposition of matters.

- 23(29)(a)(3): Failing to create, maintain, or retain accurate client ledgers for trust accounts.

- 23(29)(a)(4): Commingling client funds with other funds of the attorney and failing to create or retain sufficiently detailed records. ${ }^{8}$

James did not respond to the Verified Complaint for Disciplinary Action filed

2. 70 N.E.3d 346 (Ind. 2017).

3. Id. at 347 .

4. Id.

5. Id. at 348 .

6. Id.

7. Id.

8. Id. 
against him. ${ }^{9}$ He did not appear for the scheduled trial on the matter. ${ }^{10} \mathrm{He}$ did not file with the supreme court a petition for review of the hearing officer's report. ${ }^{11}$ His finding of ethical misconduct is essentially a judgment by default. This failure to cooperate in the discipline process is a violation of Professional Conduct Rule 8.1(b), and James was so charged in addition to the other violations. ${ }^{12}$ This Rule requires every lawyer to participate and cooperate with any discipline investigation or prosecution. ${ }^{13}$ Likewise, the Indiana Admission and Discipline Rules place an obligation on every lawyer to cooperate with a discipline investigation. ${ }^{14}$

James's failure to cooperate in the discipline process was a focal point of the court in deciding to disbar him for his misconduct. " "Respondent has not participated in these proceedings or filed a brief urging a different sanction, and we have disbarred other attorneys who have demonstrated similar unfitness to be entrusted with the responsibilities that accompany a license to practice law in this state." 16

\section{$B$. In re John Downey Pierce ${ }^{17}$}

Like Donald James, John Downey Pierce also failed to participate in his license discipline action. He did not appear, respond, or petition the supreme court for review of the hearing officer's report. ${ }^{18}$ Judgment on the Disciplinary Complaint was granted and the supreme court concurred in the hearing officer's findings of fact. ${ }^{19}$

The uncontested facts were based in three Counts of misconduct. In the first Count, Pierce commingled personal funds with client funds in his trust account. ${ }^{20}$

9. Id. at 347 .

10. Id.

11. Id.

12. Id. at 348 .

13. Ind. PROF'L CONDUCT R. 8.1(b) (2017):

An applicant for admission to the bar, or a lawyer in connection with a bar admission application or in connection with a disciplinary matter, shall not: . . (b) fail to disclose a fact necessary to correct a misapprehension known by the person to have arisen in the matter, or knowingly fail to respond to a lawful demand for information from an admissions or disciplinary authority, except that this Rule does not require disclosure of information otherwise protected by Rule 1.6.

14. IND. ADMIS. Disc. R. 23, § 10.1(a) (2017) ("Duty to cooperate. It shall be the duty of every attorney to cooperate with an investigation by the Disciplinary Commission, accept service, and comply with the provisions of this Rule.").

15. In re James, 70 N.E.3d at 348-49.

16. Id. at 349 .

17. 80 N.E.3d 888 (Ind. 2017)

18. Id. at 889 .

19. Id. at 890 .

20. Id. at 889-90. 
He also paid personal expenses from the trust account and failed to keep sufficient client ledgers for deposits and withdrawals. ${ }^{21}$ During the initial investigation of this Count, Pierce produced false banking records to the Commission. ${ }^{22}$

The second Count of misconduct arose from Pierce failing to appear at least twice for an uncontested adoption matter and failed to complete the case paperwork as ordered by the trial court. ${ }^{23}$

The third Count of misconduct arose from Pierce's failure to cooperate with the Commission's investigation of a third independent matter. ${ }^{24}$

The factual basis for the misconduct was concise, but the number of violations of the Rules of Professional Conduct were plentiful. They included:

- 1.3: Failing to act with reasonable diligence and promptness.

- 1.15(a): Failing to create or maintain complete records of client trust account funds, and commingling client and attorney funds.

- 3.2: Failing to expedite litigation consistent with the interests of a client

- 3.4(c): Knowingly disobeying a court order and an obligation under the rules or an order of a court

- 8.1(a): Knowingly making a false statement of material fact to the Disciplinary Commission in connection with a disciplinary matter.

- 8.1(b): Failing to respond in a timely manner to the Commission's demands for information.

- 8.4(a) and (b): Committing a criminal act (conversion or attempted conversion) that reflects adversely on the lawyer's honesty, trustworthiness, or fitness as a lawyer.

- 8.4(c): Engaging in conduct involving dishonesty, fraud, deceit, or misrepresentation.

- 8.4(d): Engaging in conduct prejudicial to the administration of justice. $^{25}$

Trust account procedural rules housed in the Indiana Rules of Admission and Discipline $^{26}$ were also violated. They included:

- 23(29)(a)(3): Failing to create, maintain, or retain accurate client ledgers for trust accounts.

- 23(29)(a)(4): Commingling client funds with other funds of the

21. Id. at 889 .

22. Id.

23. $I d$.

24. Id. at $889-90$.

25. Id. at 890 .

26. Admission and Discipline Rule 23 was amended effective January 1, 2017. The citations herein are to the version of Rule 23(29) in effect at the time of Respondent's misconduct. 
attorney and failing to create or retain sufficiently detailed records. ${ }^{27}$

A majority of the court imposed disbarment on Pierce. ${ }^{28}$ Both Justices Massa and Slaughter dissented to the sanction, believing that disbarment was too harsh. ${ }^{29}$ They both would have imposed a three-year license suspension upon Pierce. ${ }^{30}$ It appears from the majority opinion that the court was swayed to disbarment by the serial nature of Pierce's non-cooperation. ${ }^{31}$ They referenced in a footnote that Pierce was the subject of five different non-cooperation proceedings in 2016 alone.$^{32}$ Failing to participate in the trial proceedings of this cause of action only served to heighten his past non-cooperation. ${ }^{33}$

Similar to both the Pierce and James matters, the 2017 case of In re Andrew Straw $^{34}$ involved a non-participating respondent. This case was decided by the less analytical Order of Discipline rather than a full Per Curiam Opinion. ${ }^{35}$ What is unique about the Straw matter is that the Respondent voluntarily chose not to participate in his own trial. ${ }^{36} \mathrm{He}$ even filed a document in the cause of action that was identified on the supreme court's docket entry as follows:

"5/6/2016 Document Filed Attorney: Andrew Straw Party Andrew Straw

Notice: I refuse to Participate Certificate of Service-Mailed $05 / 06 / 2016^{\prime 37}$

Straw also sent an email to the Disciplinary Commission and the secretary of the Hearing Officer presiding over his case stating his refusal to participate in the proceedings. Dated Friday, May 6, 2016, 12:35 AM, Straw's communication read:

"Dear Indiana Attorney Disciplinary Commission, Ms. Ordway, and Ms Kosta: I refuse to participate in the proceeding against me further due to its discriminatory and retaliatory nature against my disabilities and my work for disability rights. Please see attached filing I made with the Indiana Supreme Court e-filing system this evening. Sincerely, Andrew

\section{Id. at 890 .}

28. See generally id.

29. Id. at 891 .

30. Id.

31. Id.

32. Id. at 889, n. 1 .

33. Id. at 890 .

34. 68 N.E.3d 1070 (Ind. 2017).

35. See generally id.

36. Id. at 1072.

37. See Chronological Case Summary, Straw, 68 N.E.3d 1070 (No. 98S00-1601-DI-00012), https://public.courts.in.gov/mycase/\#/vw/CaseSummary/eyJ2Ijp7IkNhc2VUb2tlbiI6IlpXRTFO VFF3T0RFd01qWXdPamt3TWpJNU16SX1OV1E9In19 [https://perma.cc/9LWT-KLB3] (entry dated 5/06/2016). 
$\operatorname{Straw}^{38}$

The rationale behind Straw's refusal to participate was his belief that he was being persecuted by the supreme court and the Disciplinary Commission for his advocacy of disabled persons. ${ }^{39}$ However, Straw's misconduct was rooted in bringing four frivolous causes of action under the Americans with Disabilities Act, each alleging disability discrimination. ${ }^{40}$ The court rebuked his persecution stance by stating, "In sum, Respondent does not face discipline for standing up for disabled person's rights, as he perceives, but rather for having done so incompetently." ${ }^{\prime 1}$ His four violations of Professional Conduct Rule $3.1^{42}$ resulted in a suspension of 180 days without automatic reinstatement with Justice David dissenting that the sanction was insufficient. ${ }^{43}$

\section{In re Everett Powell II ${ }^{44}$}

Everett Powell II was already removed from the practice of law for prior misconduct while he engaged in additional acts of misconduct. ${ }^{45}$ He received a 120-day license suspension without automatic reinstatement in 2011 for collecting an unreasonable fee from a vulnerable client. ${ }^{46}$ His further misconduct was exposed during his three separate attempts at reinstating his suspended license. ${ }^{47}$ The court sternly proclaimed, "The grounds for the instant charges . . . are but the culmination of a years-long endeavor to game the system. That endeavor ends today." 48

During his first attempt at reinstatement, it was proved that Powell continued to practice law during his period of suspension. ${ }^{49}$ While doing so, he failed to

38. Indiana Supreme Court Clerk, Record of proceedings, Exhibit \#51, page 759 (internal court document).

39. In re Straw, 68 N.E.3d at 1073.

40. Id. at 1071-72.

41. Id. at 1073 .

42. See Ind. Prof'L Conduct R. 3.1 (2017):

\section{Meritorious Claims and Contentions}

A lawyer shall not bring or defend a proceeding, or assert or controvert an issue therein, unless there is a basis in law and fact for doing so that is not frivolous, which includes a good faith argument for an extension, modification or reversal of existing law. A lawyer for the defendant in a criminal proceeding, or the respondent in a proceeding that could result in incarceration, may nevertheless so defend the proceeding as to require that every element of the case be established.

43. In re Straw, 68 N.E.3d at 1073.

44. 76 N.E.3d 130 (Ind. 2017).

45. Id. at 132 .

46. In re Powell, 953 N.E.2d 1060 (Ind. 2011).

47. In re Powell, 76 N.E.3d at 132.

48. Id. at 135 .

49. Id. 
appropriately maintain his trust account, forged the signatures of clients and another attorney, filed a false affidavit with the supreme court regarding his reinstatement, ${ }^{50}$ and misappropriated $\$ 5,000$ from another client. His reinstatement petition was denied. ${ }^{51}$

Only three days after his first reinstatement petition was denied, he filed a second petition for reinstatement. ${ }^{52}$ The hearing officer in the second petition found that Powell continued to engage in dishonesty, including the filing of two subsequent false or misleading affidavits with the supreme court, filed meritless pleadings, engaged in verbally aggressive attitude and behavior to advance his position for reinstatement, and made a belated attempt at nominal restitution to the victim of his original misconduct suspension. ${ }^{53}$ Powell's second petition for reinstatement was denied. ${ }^{54}$

In preparation for a third attempt at reinstatement, Powell met with the victim of his original misconduct, who was now residing in Iowa. ${ }^{55}$ He had her sign a document stating that he had given her $\$ 15,000$ in restitution, but informed her that he only had $\$ 1,500$ to give her at that time. ${ }^{56}$ Powell assisted the victim in executing the document before a notary public and gave her $\$ 1,500 .^{57} \mathrm{He}$ instructed the victim that if anyone from Indiana called her she should say nothing. ${ }^{58}$

In his third petition for reinstatement, Powell falsely represented that he had paid full restitution of $\$ 15,000$ to the victim. ${ }^{59}$ Powell eventually withdrew the third petition when he learned that the Disciplinary Commission was going to take a trial deposition of the victim. ${ }^{60}$ Nevertheless, the Commission proceeded with the deposition with permission of Powell's counsel. ${ }^{61}$ Neither Powell nor his counsel attended the deposition. ${ }^{62}$

Because of that deposition, the Commission charged Powell with new

50. See generally id. IND. ADMIS. \& Disc. R. 23(18)(b)(2)(i) and 23(26)(c)(7) require a suspended lawyer to file a notification affidavit with the supreme court stating that the lawyer has fully complied with the provisions of the suspension order and the Rules applicable to a suspended lawyer.

51. In re Powell, 76 N.E.3d at 132.

52. Id. at 132. Subsequent to the filing of the second petition for reinstatement, the supreme court amended Admission and Discipline Rule 23 and created a new Subsection (b)(2)(iii), which requires that twelve months must have passed since the denial of a prior petition for reinstatement before a subsequent petition can be filed.

53. Id. at 132-33.

54. Id. at 133 .

55. Id.

56. $I d$.

57. Id.

58. Id.

59. Id.

60. Id.

61. Id.

62. Id. 
misconduct related to his attempt to con the restitution matter. ${ }^{63}$ Powell's violation included Professional Conduct Rules:

- 3.3(a)(1): Making a false statement of fact to a tribunal or failing to correct a false statement of material fact previously made;

- 3.4(b): Falsifying evidence; and

- 8.4(c): Engaging in conduct involving dishonesty, fraud, deceit or misrepresentation. $^{64}$

Powell's defense to the charges was tainted with hubris. His defense to the Rule 3.3(a)(1) violation was that a false statement in a filed pleading was attributable to his counsel because counsel prepared the document. ${ }^{65}$ He ignored the fact that he was the supplier of the false evidence to his counsel. Assuming arguendo that his counsel was at fault, Rule 3.3(a)(1) also imposed a duty upon Powell to correct any false statement of material fact that he previously made. ${ }^{66}$ He failed to do so. ${ }^{67}$

Further arrogance was displayed in his defense to the Rule 3.4(b) charge. Powell contended that preparation of a false receipt at the time of the payout to the victim is not the same thing as falsifying evidence at the time of proffer to the tribunal. ${ }^{68}$ His argument suggested that falsification must occur contemporaneously when the receipt was tendered to the tribunal as evidence in the proceeding. ${ }^{69}$ Under this premise, the preparation of false evidence in anticipation of a future trial would be excusable, which the court soundly rejected and permanently disbarred Powell. ${ }^{70}$

\section{THE OTHER PER CURIAM OPINIONS}

\section{$A$. In re Terry $\mathrm{Smith}^{71}$}

The Respondent, Terry Smith, received a favorable judgment in this matter. The case arose from a re-trial after appeal ${ }^{72}$ of a child molesting conviction. The first conviction was overturned due to a violation of the defendant's Fifth Amendment rights. ${ }^{73}$ Smith was the deputy prosecutor at both the initial trial and

63. Id

64. Id.; see also IND. PROF'L CONDUCt R. 3.3(a)(1), 3.4(b), 8.4(c) (2017).

65. In re Powell, 76 N.E.3d at 134.

66. Id.

67. Id.

68. Id.

69. Id.

70. Id. at 133-35.

71. 60 N.E.3d 1034 (Ind. 2016)

72. Bean v. State, 973 N.E.2d 35 (Ind. Ct. App.), trans. denied, 978 N.E.2d 416 (Ind. 2012).

73. In re Smith, 60 N.E.3d at 1036. 
the re-trial. ${ }^{74}$ Error occurred in the second trial in the form of prosecutorial misconduct and the conviction was reversed again. ${ }^{75}$

In the child molestation re-trial, Smith was under an Order in Limine to not engage a particular line of questioning that could lead to improper vouching for the truthfulness of a child witness. ${ }^{76}$ Both a police witness and a Department of Child Services witness nevertheless breached the trial court's order. ${ }^{77}$ The court of appeals, in reviewing the criminal conviction appeal, found that Smith had opened the door for the prohibited answers. ${ }^{78}$ The Disciplinary Commission used this appellate decision as a basis for bringing ethical misconduct charges against Smith. ${ }^{79}$

The Disciplinary Commission argued that the court of appeals finding of prosecutorial misconduct committed by Smith conclusively established his misconduct for the license discipline cause of action..$^{80}$ The supreme court rejected this threshold argument. It stated that there was not an alignment of parties to the issue of prosecutorial misconduct in both the trial case and the lawyer discipline case. ${ }^{81}$ Smith was not a party to the child molestation matter and was not able to defend himself individually to the accusations raised in that case's criminal appeal. There was no privity of parties between the two causes of action. ${ }^{82}$

The supreme court ruled differently than the court of appeals, finding that Smith's questioning of either witness was not phrased in a way to elicit the answer given. $^{83}$ Rather, the police officer and the child services worker volunteered the answers given and no lawyer misconduct occurred. ${ }^{84}$ One must remember that the supreme court's ruling in the Smith discipline case is not a statement in review of the court of appeals decision overturning the criminal conviction of defendant Bean. The Smith discipline matter is an original action in the supreme court addressing lawyer ethics and licensing, and is independent of the court of appeals application of the appellate standard of prosecutorial misconduct in the criminal matter.

A third issue in this case surrounded Smith's closing argument to the jury and whether he argued that the police witness "substantiated" the allegations against the defendant which would have been a violation of the Order in Limine. ${ }^{85}$ Although the written trial transcript indicated that Smith uttered the word

74. See generally id.

75. Bean v. State, 15 N.E.3d 12 (Ind. Ct. App.), trans. denied, 18 N.E.3d 1005 (Ind. 2014).

76. In re Smith, 60 N.E.3d at 1035-37.

77. Id. at 1037.

78. Bean, 15 N.E.3d at $16,21-22$.

79. Verified Complaint, In re Smith, 60 N.E.3d 1034 (No. 91S00-1603-DI-136, filed March $18,2016)$.

80. In re Smith, 60 N.E.3d at 1036.

81. Id.

82. Id.

83. Id. at 1037.

84. Id. at 1037-38.

85. See generallyid. 
"substantiated," an audio playing of the trial tape indicated that the written transcript was in error. ${ }^{86}$ Smith was cleared of this third accusation of misconduct. ${ }^{87}$

\section{$B$. In re Narles Coleman ${ }^{88}$}

The listing of ethical rules violated by Coleman far out-distances the brevity of the court's discussion and analysis of Narles Coleman's misconduct.

- 1.1: Failing to provide competent representation.

- 1.2(a): Failing to abide by a client's decisions concerning the objectives of representation.

- 1.3: Failing to act with reasonable diligence and promptness.

- 1.4(a)(3): Failing to keep a client reasonably informed about the status of a matter.

- 1.4(b): Failing to explain a matter to the extent reasonably necessary to permit a client to make informed decisions.

- 1.5(a): Making an agreement for, charging, or collecting an unreasonable fee.

- 1.5(b): Failing to communicate the basis or rate of the fee and expenses for which a client will be responsible before or within a reasonable time after commencing the representation.

- 1.8(a): Entering into a business transaction with a client (a revised fee agreement) unless the transaction is fair and reasonable, the terms are fully disclosed in writing, the client is given written advice of the desirability of seeking and the opportunity to seek the advice of independent counsel, and the client consents in writing to the transaction.

- 1.16(d): After the termination of representation, failing to protect a client's interests and failing promptly to return to a client case file materials to which the client is entitled.

- 3.1: Asserting a position for which there is no non-frivolous basis in law or fact.

- 3.2: Failing to expedite litigation consistent with the interests of a client.

- 3.3(a)(3): Offering evidence the lawyer knows to be false, and failing to take reasonable remedial efforts after becoming aware that a witness called by the lawyer offered false material evidence.

- 3.4(c): Knowingly disobeying an obligation under the rules of a tribunal.

- 4.1(a): Knowingly making a false statement of material fact to a third person in the course of representing a client.

86. Id. at 1037.

87. Id. at 1038 .

88. 67 N.E.3d 629 (Ind. 2017). 
- 7.2(b) (2007): Using a public communication containing a false, fraudulent, misleading, deceptive, self-laudatory or unfair statement or claim.

- 7.2(c)(3) (2007): Making a statement intended or likely to create an unjustified expectation.

- 7.3(c) (2007): Solicitation of professional employment without the words "Advertising Material."

- 8.4(b): Committing a criminal act that reflects adversely on the lawyer's honesty, trustworthiness, or fitness as a lawyer.

- 8.4(c): Engaging in conduct involving dishonesty, fraud, deceit, or misrepresentation.

- 8.4(d): Engaging in conduct prejudicial to the administration of justice. ${ }^{89}$

In the first count of misconduct, Coleman took on a child molestation client. The representation was a mess from its initiation..$^{90}$ Coleman solicited the client through false advertising claiming that he was associated with "The Cochran Firm" founded by famous lawyer Johnnie Cochran, and told the client that he would receive the best possible representation. ${ }^{91}$ In fact, Coleman had minimal criminal law experience and no experience in child molestation cases. ${ }^{92}$

After paying a $\$ 4,000$ flat fee, the client had difficulty communicating with Coleman, meeting with Coleman, or preparing a defense with him. ${ }^{93}$ Coleman missed court hearings, misinformed the client of evidentiary matters, deceived the client into executing a new fee agreement, and negotiated a plea without consulting the client. ${ }^{94}$

The client fired Coleman and hired new counsel with the charges ultimately being dismissed..$^{95}$ Coleman did not withdraw his appearance despite being fired nor did he promptly forward the client's file to new counsel. ${ }^{96}$ It took a show cause proceeding to be initiated before he finally surrendered the client's file. ${ }^{97}$

In a second count of misconduct, Coleman was convicted by a jury of domestic battery, a class A misdemeanor. ${ }^{98}$ This act supported the violation of Professional Conduct Rule 8.4(b). ${ }^{99}$

The only analysis performed by the court in this Per Curiam Opinion

89. Id. at 631-32.

90. Id. at 630 .

91. Id.

92. Id.

93. Id.

94. Id.

95. Id. at 631.

96. Id.

97. Id.

98. Id.

99. Id. at 631-32. 
regarded the sanction. ${ }^{100}$ The court credited Coleman with the mitigating factors of no prior ethics discipline and only a single client suffering from most of the misconduct. ${ }^{101}$ However, the court found much in aggravation of the sanction. It noted that the misconduct was "wide-ranging, pervasive, retaliatory, and deceptive." ${ }^{102}$ The court also noted that Coleman used his wife to deceive the client and later committed domestic battery against her. ${ }^{103}$ The court described Coleman's misconduct as "systemic malfeasance" and even criticized his selfrepresentation in the discipline process as being "less-than-effective." ${ }^{104}$ For this misconduct, Coleman's license was suspended for two years without automatic reinstatement. ${ }^{105}$

\section{In re Gene Emmons ${ }^{106}$}

This matter generated a Per Curiam Opinion despite the parties coming to an agreement for disposition in which Emmons would be suspended from the practice of law for at least three years without automatic reinstatement. ${ }^{107}$ The agreement of the parties reduces the ability of the court to fully analyze the Respondent's misconduct. Once again, the court spent its time analyzing an appropriate sanction rather than interpreting the Professional Conduct Rules. ${ }^{108}$

Emmons was appointed by a trial court to serve as guardian of an incapacitated eighty-eight year old woman. ${ }^{109} \mathrm{He}$ became a signatory on two bank accounts belonging to the Ward. ${ }^{110} \mathrm{He}$ wrote three checks to himself on the Ward's account for purported legal fees earned totaling $\$ 20,000 .{ }^{111}$ He never sought permission of the trial court for these self-serving disbursements. ${ }^{112}$

While representing the Ward, Emmons twice failed to comply with court orders directing him to prepare an accounting. ${ }^{113} \mathrm{He}$ also failed to appear at a show cause hearing to answer as to his failure to comply with two accounting demands. ${ }^{114}$ His neglectful attitude continued after the Disciplinary Commission's investigation commenced. He failed to respond to an investigative inquiry. ${ }^{115} \mathrm{He}$

100. See generally id.

101. Id. at 632 .

102. Id.

103. Id.

104. Id.

105. Id. at 632-33.

106. 68 N.E.3d 1068 (Ind. 2017).

107. Id. at 1069.

108. See generallyid.

109. Id. at 1068.

110. Id.

111. Id.

112. Id.

113. Id. at 1069.

114. Id.

115. Id. 
failed to answer a show cause order of the supreme court. ${ }^{116}$ He failed to comply with a subpoena duces tecum in the discipline action, and when he eventually did comply, it was an incomplete response. ${ }^{17}$

The court found Emmons's misconduct to consist of violation of the following Professional Conduct Rules:

- 1.15(a): Failing to maintain complete records of client trust account funds and keep them for a period of five years after termination of the representation.

- 3.4(c): Knowingly disobeying court orders.

- 8.1(b): Knowingly failing to respond to a lawful demand for information from a disciplinary authority.

- 8.4(b): Committing a criminal act that reflects adversely on the lawyer's honesty, trustworthiness, or fitness as a lawyer.

- 8.4(c): Engaging in conduct involving dishonesty, fraud, deceit, or misrepresentation.

- 8.4(d): Engaging in conduct prejudicial to the administration of justice.

- Trust Account Overdraft Reporting Rule 4(A)(2): Failing to notify a bank that an account was a client trust account subject to overdraft reporting rules. ${ }^{118}$

By a 4-1 vote, the court accepted the conditional agreement, which called for a three-year suspension without automatic reinstatement. ${ }^{119}$ Justice Steven David voted to reject the agreement. ${ }^{120}$ In accepting the parties' proposed resolution, the majority cited as persuasive factors its desire to foster agreed resolutions between parties in attorney discipline cases, the inexperience and lack of prior discipline by the Respondent, and the protection to the public afforded by the discretionary reinstatement process. ${ }^{121}$

It is worth noting that had Emmons petitioned the trial court to approve attorney's fees and was able to account to the court that he earned the fee, he might not have faced this prosecution. Depending on the amount of work done and the length of time that the Ward was under the guardianship, a \$20,000 fee might not be unreasonable. ${ }^{122}$ Emmons error was the use of self-help to grab the fee followed by inattention to the trial court's supervision authority.

116. $I d$.

117. Id.

118. Id. at 1069; Trust Account Overdraft Reporting Rule 4(A)(2) (2017).

119. In re Emmons, 68 N.E.3d at 1069-70.

120. Id. at 1070.

121. Id. at 1069 .

122. See IND. CODE $§ 29-3-9-3$ (2018) (regarding compensation of a guardian); see also id. $\S 29-3-9-6$ (regarding account approval by the court); id. § 29-3-9-9 (regarding guardianship attorney's fees). 


\section{In re Douglas Krasnoff ${ }^{123}$}

Douglas Krasnoff represented the same client in two separate wage claim actions against the client's employer, General Motors (GM) ${ }^{124}$ In both cases the fee agreement was complicated. ${ }^{125}$ The court was able to succinctly summarize the fee outcome by stating, "When all is said and done, between the two cases Respondent collected over $\$ 50,000$ for himself and nothing for Client, and Respondent claims Client still owes him money."126

In the second case, Krasnoff collected from GM and for himself $\$ 20,000$ towards his own fee. ${ }^{127}$ Essentially, he took his fee off the top but then failed to pursue the $\$ 10,000$ balance of the agreed settlement owed by GM to the client. ${ }^{128}$ Also, the settlement statement that Krasnoff had his client sign in the second GM matter altered the terms of the fee arrangement that was negotiated with the client five years earlier. ${ }^{129}$ Krasnoff never advised his client that the fee was being

123. 78 N.E.3d 657 (Ind. 2017).

124. Id. at 659 .

125. Id.

The fee agreement provided that Client pay Respondent $\$ 10,000$ as a retainer fee/fixed fee. The agreement also called for Client to pay Respondent $40 \%$ of any recovery as a "contingent fee bonus," to which the retainer fee/fixed fee would be credited. Client paid Respondent $\$ 6,000$. When the case settled in March 2006 for $\$ 3,000$, Respondent kept the entire amount (for a total of $\$ 9,000$ ), leaving Client owing $\$ 1,000$ to Respondent.

...

$[\mathrm{I}] \mathrm{n}$ a second claim ... [ $\mathrm{t}]$ he fee agreement provided that Client pay Respondent $\$ 5,000$ as a "retainer fee/fixed fee," which Client paid in full. The agreement also called for Client to pay Respondent $33 \%$ or $40 \%$ of any recovery (depending on whether the case went to trial) as a "contingent fee bonus," to which the retainer fee/fixed fee would be credited.

...

In addition to the amounts described above, Respondent charged Client $\$ 10,000$ to take an "appeal from a Magistrate Order to the District Judge" ("Appeal Fee"). Respondent also charged Client $\$ 8,000$ "to add claims to his lawsuit" ("Additional Fee"), but Respondent only belatedly attempted to add these claims to the lawsuit, was denied leave to add them, and eventually released these claims against Client's wishes.

After the Second GM Case settled for \$30,000 in 2007, Respondent had Client sign a "Settlement Agreement" that provided Respondent would receive $\$ 20,000$ in attorney fees and Client would receive $\$ 10,000$. The $\$ 5,000$ retainer Client had paid was not credited to him. Respondent did not advise Client in writing of the desirability of seeking the advice of independent counsel regarding the modification or give Client a reasonable opportunity to do so before Client signed the Settlement Agreement. Id.

126. Id. at 662 .

127. Id. at 659 .

128. Id. at 659-60.

129. Id. at 661 . 
renegotiated nor advised in writing that the client should seek independent counsel before agreeing to a fee alteration. ${ }^{130}$ This advisement is required by Professional Conduct Rule 1.8(a). ${ }^{131}$

The court only addressed one aspect of the fee and in finding it to be unreasonable, declined to address any other aspect of the fee. ${ }^{132}$ The court determined that a $\$ 10,000$ additional fee for pursuing an appeal was mischaracterized by Krasnoff. ${ }^{133}$ The action that he pursued for the client was an objection to a pretrial order and not an appeal in the traditional sense. ${ }^{134}$ Furthermore, the court found that the objection was an attempt by Krasnoff to avoid giving to GM materials that he knew GM already had. ${ }^{135}$ All of this led to the court finding a violation of Professional Conduct Rule 1.5(a) for charging an unreasonable fee. ${ }^{136}$

During a seven and one-half month period of the representation, Krasnoff's law license became suspended for not completing his continuing legal education requirements. ${ }^{137}$ During that period he continued to actively represent the client and pursue the pending claim. ${ }^{138}$ The court found this activity to be in violation of Professional Conduct Rule 5.5(a) for practicing law without a license. ${ }^{139}$

The exploitive overreach, obstreperous conduct during discipline proceedings, and lack of insight by Krasnoff persuaded the court that any imposed sanction would be subject to formal reinstatement. ${ }^{140}$ The court suspended Krasnoff's license for 180 days without automatic reinstatement. ${ }^{141}$

\section{E. In re Beau White ${ }^{142}$}

Similar to both the James and Pierce matters previously discussed, White was another respondent who failed to appear, respond, or participate in any fashion in the license discipline brought against him. ${ }^{143}$ Likewise, he did not seek from the supreme court a petition for review of the hearing officer's report. ${ }^{144}$ What

130. Id. at 659 .

131. Ind. PROF'L CONDUCT R. 1.8(a) (2017).

132. Id. at 660 n.2.

133. $I d$.

134. Id.

135. Id. at 661 .

136. Id. at 662 .

137. Id. at 659 .

138. Id. at 660 .

139. Id.

140. Id. at 662.

141. Id. at 662-63.

142. 81 N.E.3d 211 (Ind. 2017).

143. Id.

144. Id. 
differs the White decision from the others is that he escaped disbarment. ${ }^{145}$ Again the vote was 3-2, with Justice Goff being the swing vote in favor of a three-year license suspension. ${ }^{146}$

White's misconduct was couched in two separate instances of client neglect. ${ }^{147}$ In the first Count, White appeared on the morning of a jury trial unprepared to represent a retained criminally accused client. ${ }^{148}$ When the Disciplinary Commission inquired into this neglect, White failed to cooperate. ${ }^{149}$

In the second Count of misconduct, White accepted payment from a client for representation regarding paternity and child support issues. ${ }^{150}$ White never completed the work. ${ }^{151}$ Again, he failed to cooperate with the Disciplinary Commission in its investigation into this instance of neglect. ${ }^{152}$

White's misconduct consisted of violations of Professional Conduct Rules:

- 1.3: Failing to act with reasonable diligence and promptness.

- 1.4(a)(4): Failing to comply promptly with a client's reasonable requests for information.

- 8.1(b): Failing to respond in a timely manner to the Commission's demands for information.

- 8.4(d): Engaging in conduct prejudicial to the administration of justice. ${ }^{153}$

It would appear the decisive factor in not disbarring White was the nature of the charges. White did not face any allegations of client money mismanagement or conversion, whereas James and Pierce both did. However, White had a lengthy record of prior ethical indiscretions. The court noted that White has had nine separate show cause proceedings brought against him for non-cooperation in various discipline matters since $2014 . .^{154} \mathrm{He}$ also was under a separate interim license suspension because of a felony drug conviction earlier in $2017 .{ }^{155} \mathrm{He}$ also had prior discipline from 2012 resulting in a license suspension arising from client neglect. ${ }^{156}$ Since 2008, White had been administratively suspended six times for failing to meet licensing financial obligations. ${ }^{157}$

This pattern of misconduct and lackadaisical attitude towards his licensing

145. Id. at 212 .

146. Id.

147. Id. at 211.

148. Id.

149. Id.

150. Id.

151. $I d$.

152. Id.

153. Id. at 212 .

154. Id. at $211 \mathrm{n} .1$.

155. Id.

156. In re White, 969 N.E.2d 3 (Ind.), modified by In re White, 970 N.E.2d 145 (Ind. 2012).

157. In re White, 81 N.E.3d at 212. 
responsibilities led Justices Rush and David to dissent to the sanction of suspension. ${ }^{158}$ Both believed that a sanction of greater than three years, or disbarment was appropriate. ${ }^{159}$

\section{$F$. In re Gillian DePrez Keiffner ${ }^{160}$}

Two independent child molestation convictions were overturned by the Indiana Court of Appeals due to prosecutorial misconduct by Deputy Prosecuting Attorney Gillian DePrez Keiffner. ${ }^{161}$ These judicial determinations suggested a pattern of conduct and led to Keiffner being charged with violations of Professional Conduct Rule 3.4(e) ${ }^{162}$ and 8.4(d). ${ }^{163}$

Ryan v. State ${ }^{164}$ was the first matter in which the Indiana Court of Appeals determined that Keiffner had engaged in appealable prosecutorial misconduct during trial. Her misconduct included:

- Demeaning the role of defense counsel

- Improperly vouching for the credibility of a witness

- Demeaning the right of a trial by jury

- Asking the jury to convict for reasons other than the defendant's guilt. ${ }^{165}$

158. Id.

159. Id.

160. 79 N.E.3d 903 (Ind. 2017).

161. Id. at 904 .

162. Ind. PROF’' CONDUCt R. 3.4(e) (2017) (“A lawyer shall not . . in trial, allude to any matter that the lawyer does not reasonably believe is relevant or that will not be supported by admissible evidence, assert personal knowledge of facts in issue except when testifying as a witness, or state a personal opinion as to the justness of a cause, the credibility of a witness, the culpability of a civil litigant or the guilt or innocence of an accused[.]"

163. Id. R. 8.4(d) ("It is professional misconduct for a lawyer to ... engage in conduct that is prejudicial to the administration of justice[.]").

164. 992 N.E.2d 776 (Ind. Ct. App. 2013), rev’d, 9 N.E.3d 663 (Ind. 2014).

165.

The prosecutor improperly told the jury that defense counsel employed a 'classic defense trick,' demeaning the role of defense counsel and our system of justice. Tr. at 152. We have stated that 'the jurors' estimates of the truthfulness of a witness or analysis of the evidence could be affected by the manner in which they perceive the role of defense counsel.' Bardonner, 587 N.E.2d at 1361. In addition, the jury's assessment of Z.W-B.'s credibility would have been affected by the prosecutor's improper declaration that Z.W-B. 'told you the truth of what happened' and 'has never been dishonest.' Tr. at 139, 153. Also, significantly, Ryan's exercise of his constitutional right to a jury trial was penalized when the prosecutor stated to the jury that Ryan chose to have a jury trial to try to get away with his crime. Finally, the prosecutor went beyond the evidence and improperly urged the jury to convict Ryan 'to send the message that we're not going to allow people to do this.' $I d$. at 141. Together the 
The court of appeals found that the cumulative effect of the misconduct was fundamental error resulting in an unfair trial. ${ }^{166}$ The trial conviction was reversed and remanded for a new trial. ${ }^{167}$

The Indiana Supreme Court granted transfer, reversed the court of appeals decision and reinstated the trial court conviction. ${ }^{168}$ The supreme court found that there was one instance of prosecutorial misconduct but that it did not rise to the level of fundamental error. ${ }^{169}$ The supreme court briefly mentioned that it did not approve of Keiffner's trial tactics in the case. ${ }^{170}$

The second reversal of a child molestation conviction caused by Keiffner's misconduct occurred in Brummett v. State. ${ }^{171}$ The court of appeals concluded that Keiffner had:

- Engaged in prosecutorial misconduct by improperly distinguishing between the role of the defense and the prosecution

- Improperly vouched for the credibility of a State's witnesses

- Asked argumentative and inflammatory questions ${ }^{172}$

The court found that the cumulative effect of the misconduct amounted to fundamental error." 173 The court also noted that Keiffner was the same prosecutor who had engaged in similar conduct in the Ryan decision. ${ }^{174}$

The Indiana Supreme Court granted transfer from the court of appeals and summarily affirmed the decision that fundamental error had occurred without specifically commenting on Keiffner's misconduct. ${ }^{175}$

This type of prosecutorial misconduct during trial has been problematic. In a footnote in the Ryan decision, ${ }^{176}$ the court of appeals identified the growing

cumulative effects of the prosecutor's improprieties deprived Ryan of a fair trial. $I d$. at 790-91.

166. Id. at 789-90.

167. Id. at 791 .

168. Ryan, 9 N.E.3d 663.

169. "We recognize only a single instance of prosecutorial misconduct, namely that the prosecutor improperly urged the jury to convict the defendant for reasons other than his own guilt. But we decline to conclude that the trial court erred by not correcting the prosecutor's misstatements." Id. at 672 .

170. "Thus, the doctrine of fundamental error does not overcome procedural default. While we do not endorse the prosecutor's trial tactics in this case, we affirm the judgment of the trial court." Id. at 673 .

171. 10 N.E.3d 78 (Ind. Ct. App. 2014), aff'd on reh'g, 21 N.E.3d 840, summarily aff'd in relevant part on transfer, 24 N.E.3d 965 (Ind. 2015); Ryan, 992 N.E.2d 776, rev'd, 9 N.E.3d 663.

172. Brummett, 10 N.E.3d at 88.

173. Id.

174. Id. at 83 n.5.

175. Brummett, 24 N.E.3d 965.

176. Ryan, 992 N.E.2d at 791 n.6. 
problem of prosecutorial misconduct similar to Keiffner's:

Another panel of this Court recently issued a memorandum decision in which the defendant claimed that prosecutorial misconduct resulted in reversible error. Spiegel v. State, No. 49A02-1208-CR-687, 2013 WL 1687706 (Ind.Ct.App. Apr. 18, 2013). The Spiegel court concluded that the prosecutor improperly expressed her personal opinion as to the credibility of a witness, improperly inflamed the passions or prejudices of the jury, improperly commented on the possible penal consequences of conviction, and improperly highlighted the disparate roles of the prosecution and defense. Nevertheless, the Spiegel court concluded that reversal was not warranted because as to the first instance of misconduct the evidence of guilt was abundant and therefore Spiegel was not subjected to grave peril, and as to the other three instances Spiegel waived his fundamental error claims. In his concurring opinion, Judge Friedlander observed that despite admonishment from this Court, 'instances of condemnable prosecutorial behavior continue to come before us on appeal. It would seem that our admonishments are falling on deaf ears on an all-too-regular basis.' $I d$., slip op at * 7. This case demonstrates the unfortunate result of the failure to heed our admonishments; namely, prosecutorial misconduct that requires reversal. ${ }^{177}$

Having briefly summarized what occurred in the criminal trial appeals, the discussion now shifts to the independent cause of action for Keiffner's law license sanction due to professional misconduct. Prosecutorial misconduct and professional misconduct are not synonymous. The former is an appellate standard of review. The latter is an ethical standard of professional law practice.

This Per Curiam Opinion has many interesting twists to it. First, the hearing officer in the case ruled in favor of Keiffner that no professional misconduct occurred. ${ }^{178}$ Relying on the Smith decision ${ }^{179}$ discussed earlier in this Article, the hearing officer believed that the Disciplinary Commission depended too much on the findings of the court of appeals in attempting to meet its burden of proof. The fault with this proof was a lack of privity for Keiffner since she was not a party to the criminal appeals ${ }^{180}$ in both Ryan ${ }^{181}$ and Brummet. ${ }^{182}$ The supreme court believed that the Commission had gone beyond the bare bones approach in Smith, but nevertheless accepted the hearing officer's findings and concluded that the Commission had failed to meet its burden of proof. ${ }^{183}$

Interestingly, the court acknowledged the questionable statements made by

177. $I d$.

178. In re Keiffner, 79 N.E.3d 903, 905 (Ind. 2017).

179. Id. at 905.

180. Id.

181. Ryan, 9 N.E.3d 663.

182. Brummett, 24 N.E.3d 965.

183. In re Keiffner, 79 N.E.3d at 907. 
Keiffner in her closing arguments to the juries, but appeared to create a newly recognized "heat of trial" exception for her statements. ${ }^{184}$ The court said it was "hesitant on these facts to ground a finding of professional misconduct on a post hoc parsing of semi-spontaneous oral statements made during the heat of trial." 185

Despite ruling in Keiffner's favor, the court then launched into a stern reprimand of her specific acts.

We caution that by no means should our opinion today be read as an endorsement of Respondent's actions. For the reasons outlined in Ryan and Brummett, we continue to disapprove of arguments that invite a conviction for reasons other than a defendant's guilt, impugn the integrity of defense counsel, or otherwise create a "good guy / bad guy dichotomy" between the respective roles of the State and defense counsel. Arguments of this nature, whether intentionally or carelessly made, endanger the defendant's right to a fair trial and the probability that any resulting conviction will survive appellate review. It is no small thing for a conviction to be reversed and a case retried, particularly in cases such as these involving allegations of sex offenses against children; it delays justice, places a strain on limited judicial resources, and forces victims and others to testify yet again. Respondent's conduct in these cases caused one conviction to be lost, placed another at unnecessary risk of being lost, and placed herself at risk of professional discipline. Prosecutors would be well-advised to exercise better care in crafting their presentations to juries than Respondent did here. ${ }^{186}$

This written rebuke of her actions seems to contradict its ruling in favor of Keiffner. The court recognizes the content of her final argument. How can the court write about these facts without the Commission having presented them in its case in chief? Wouldn't the record of the professional misconduct trial serve as the court's source for the fact that Keiffner invited conviction for reasons other than guilt, impugned defense counsel's integrity, or created a "good guy/bad guy dichotomy."

The court goes so far as to call out Keiffner individually. "Respondent's conduct in these cases caused one conviction to be lost, placed another at unnecessary risk of being lost, and placed herself at risk of professional discipline." ${ }^{187}$ This statement recognizes actual harm caused by Keiffner.

This rebuke contradicts the court's determination that the Commission's prosecution was "structured largely around the notion that a criminal appellate finding of prosecutorial misconduct was dispositive of the question of professional misconduct in disciplinary proceedings." 188 And, in the alternative, if the court is gleaning these facts from the criminal case appeals of Ryan and

184. Id. at 906 .

185. Id.

186. Id. at 907 .

187. Id.

188. Id. at 906 . 
Brummett, then isn't it accepting them into the record of the Keiffner decision an act of overruling the hearing officer's decision?

A final curiosity in this Per Curiam Opinion is the court's customary disposition paragraph of the case. It reads in part, "A majority of the Court concludes that the Commission has not met its burden of proving by clear and convincing evidence that Respondent violated Indiana Professional Conduct Rules 3.4(e) or 8.4(d)."'189

Traditionally, if not all justices concur in the Opinion, or participate in the Opinion, then the justices are named individually as to who concurred, who dissented, or who did not participate. The phrase "[a] majority of the Court" suggests that there was a dissent, or two. ${ }^{190}$ Who was in the "majority"? No names of the justices are ascribed to the Opinion. What is most curious is that whomever was not in the majority did not choose to be identified.

The court's disposition in this case can best be described as a dismissal with public reprimand.

\section{$G$. In re Joseph Johnson III $^{191}$}

At the time of his misconduct, Johnson was the Chief Public Defender Adams County, Indiana. ${ }^{192}$ In 2010, while married, Johnson had an affair for several months with "Jane Doe" (hereinafter "J.D."). ${ }^{193}$ Four years later, J.D. was at the local courthouse as a defendant to an operating while intoxicated charge. ${ }^{194}$ Johnson saw J.D. at the courthouse and renewed acquaintance with her, ultimately leading to a dinner date, despite Johnson still being married. ${ }^{195}$ After the date, Johnson continued to pursue J.D., but she rebuffed his multiple attempts to rekindle the flame. ${ }^{196}$ J.D.'s repeated rejections did not stop Johnson and his contacts with her became persistent and overbearing. ${ }^{197}$

Johnson called, texted, used Facebook, appeared uninvited at her apartment, prevented J.D. from closing her apartment door, tried to reach J.D. through her roommate, and left messages at her door. ${ }^{198}$ She pleaded with Johnson to leave her alone. ${ }^{199}$ Police had to intervene on J.D.'s behalf several times and issued a No Trespass Order to him. ${ }^{200}$ The police and court action only emboldened Johnson. In one instance, he awaited outside J.D.'s residence until the school bus

189. Id. at 907.

190. Id.

191. 74 N.E.3d 550 (Ind. 2017).

192. Id. at 551.

193. Id.

194. Id.

195. Id.

196. Id.

197. Id.

198. Id.

199. Id.

200. Id. 
dropped off her children. ${ }^{201}$ When she opened the door for her children, Johnson was also there to meet her. ${ }^{202}$ Eventually, J.D. secured a protective order from the court against Johnson. ${ }^{203}$

The protective order did not stop Johnson. He tried to leverage his public defender role with J.D.'s probation officer in the impaired driving case. ${ }^{204} \mathrm{He}$ told the probation officer that J.D. had violated probation by having a glass of wine. ${ }^{205}$ Because of this communication, J.D. encountered a probation violation resulting in a ten-day suspended jail sentence. ${ }^{206}$ Johnson also tried to leverage his position by threatening to have J.D.'s children taken away from her and by claiming he was an "old buddy" with the judge. ${ }^{207}$

Johnson was criminally charged and convicted of trespass. ${ }^{208}$ His sentence included a no contact order with J.D. ${ }^{209}$ His appeal of that conviction was unsuccessful. ${ }^{210}$ After his conviction, he tried to reach J.D. at her place of employment. ${ }^{211} \mathrm{He}$ also saw a friend of J.D.'s at the courthouse. ${ }^{212}$ The friend was there for court business related to her recent arrest for driving while suspended. ${ }^{213}$ Johnson told J.D.'s friend to meet him at his office and to enter through the back door. ${ }^{214} \mathrm{He}$ tried to persuade the friend to have J.D. call him and he asked her for J.D.'s new address. ${ }^{215}$

He continued his campaign of intimidation by threatening the police officer investigating new criminal allegations of violating the orders of protection, finding J.D.'s new residence, repeatedly driving by her new residence, parking across the street from her new residence, and slowly driving by her new residence and staring at J.D. when present. ${ }^{216}$

The commission cited Johnson for violating the following Rules of Professional Conduct:

- 8.4(b): Committing a criminal act that reflects adversely on the lawyer's honesty, trustworthiness, or fitness as a lawyer.

201. Id.

202. $I d$.

203. Id.

204. Id.

205. Id.

206. Id.

207. Id. at 553 n.2.

208. Id. at 551 .

209. Id.

210. Johnson v. State, No. 01A02-1501-CR-00025, 2015 WL 3638228 (Ind. Ct. App. 2015) (unpublished opinion).

211. In re Johnson, 74 N.E.3d at 551-52.

212. Id. at 552 .

213. Id.

214. Id.

215. Id.

216. Id. 
- 8.4(d): Engaging in conduct prejudicial to the administration of justice.

- 8.4(e): Stating or implying an ability to influence improperly a government agency or official. ${ }^{217}$

Johnson defended his conduct on two theories. First, he claimed that there was no nexus between his conduct and the practice of law. ${ }^{218} \mathrm{He}$ argued that his private conduct outside the practice of law did not fall within the bounds of the Rules of Professional Conduct. Second, he claimed that his behavior was excused by mental illness. ${ }^{219}$

The court found his nexus claim "wholly unavailing." 220 It reasoned that Johnson's position as chief public defender played an integral role in his misconduct. ${ }^{221}$ The court rejected the argument that Johnson was fulfilling professional obligations when he reported J.D. to the probation officer. Instead, it found that he leveraged his position with the probation officer to pursue his own desires. ${ }^{222}$ The court also pointed out that Johnson's criminal conduct of texting in violation of the protection order had a nexus to his practice of law because he texted to J.D. that he would be meeting with both the probation officer and the judge. ${ }^{223} \mathrm{He}$ couldn't hide behind professional duty if he was violating the protection order, the probation order, and committing a crime when he texted his implied threats to J.D. ${ }^{224}$

Johnson also used the nexus argument in an attempt to mitigate the sanction. He argued that even if there is professional misconduct, it does not arise out of his law practice, but is independent personal misconduct. The court categorically rejected this argument. ${ }^{225}$

Johnson proved that during this fourteen-month episode of harassment of J.D. he was suffering depression, manic episodes, and bipolar disorder ${ }^{226}$ The court accepted this fact as a sanction mitigator, but rejected it as an excuse for culpability of his misconduct actions. ${ }^{227}$ It noted that some of his misconduct occurred during periods of receiving treatment when his mental illness appeared to be subsided.228 The court suspended Johnson's law license for one year without

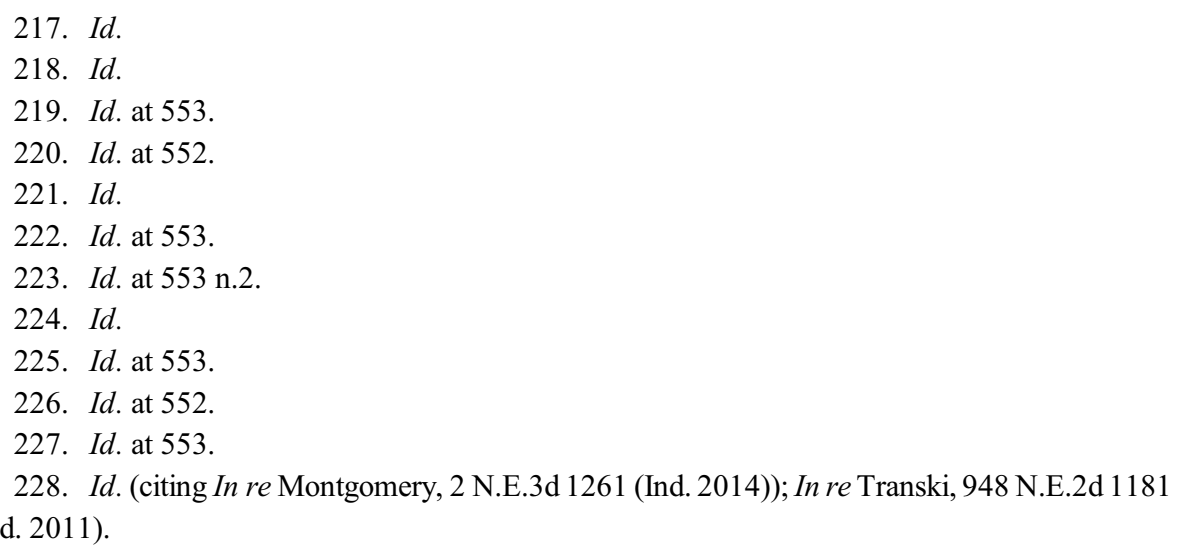


automatic reinstatement. $^{229}$

\section{THE RENT-A-LICENSE CASES}

Lawyer rent-a-license schemes are highly attractive to prospective clients who have basic run-of-the-mill legal issues. Although they are posed as an inexpensive, straightforward and simplified alternative to standard legal practices, these schemes are often fraught with conduct that violates professional conduct rules which results in harm to clients.

With largely parallel fact patterns, three lawyers independently partnered with out of state legal service groups and knowingly utilized non-lawyer assistants to solicit prospective clients, evaluate their legal claims, facilitate the signing of representative agreements and directly handle attorney's fees, yet each received different penalties. The court issued two Per Curiam opinions and declined to issue one for the third, most likely because of its nature as a conditional agreement between the parties. ${ }^{230}$

When rendering its judgments, the court utilized sliding scales of aggravating and mitigating factors. The most persuasive mitigating factors included a lack of actual harm to clients, the misconduct playing a small role in the attorney's overall practice, cooperation with disciplinary proceedings, remorse, and a lack of disciplinary history. On the opposite end of the scale, the most persuasive aggravating factors included lengthy disciplinary history, nature of the fee agreement, actual harm, attitude during disciplinary proceedings, and the extent of the unauthorized practice of law.

\section{$A$. In re Divina Westerfield ${ }^{231}$}

Indiana lawyer, Divina Westerfield, committed unauthorized practice of law in the state of Florida. ${ }^{232}$ However, she was prosecuted and disciplined in Indiana pursuant to Indiana Professional Rule of Conduct 8.5, which subjects a lawyer admitted to practice in this jurisdiction to its disciplinary authority, regardless of where the lawyer's conduct occurs. ${ }^{233}$

Westerfield's first count of misconduct began when she associated herself with Wayne Tope, a non-lawyer marketing representative. ${ }^{234}$ Tope advertised quiet title actions for homeowners to gain leverage against mortgage holders and recruited several homeowners to be represented by Westerfield. ${ }^{235}$ Once recruited, Westerfield's clients entered into flat fee contracts which were executed by Tope. ${ }^{236}$ Her clients sent Tope a series of post-dated monthly installment checks

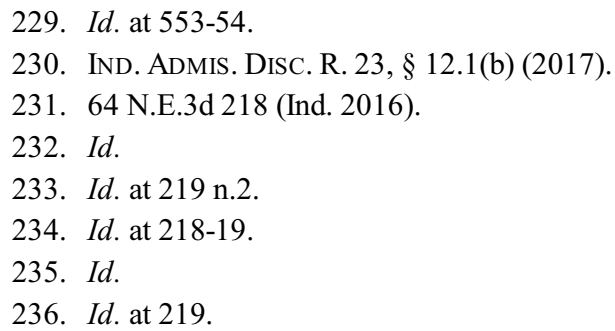


payable to Westerfield, which Westerfield then deposited into an IOLTA (interest on lawyer trust account) account within her control. ${ }^{237}$

Westerfield registered her solo-practice as a limited liability company with the Florida Secretary of State. ${ }^{238}$ Westerfield proceeded to enter into a series of partnership agreements with Florida licensed attorneys, the likes of which did not comport with the state's laws governing interstate law firm operations. ${ }^{239}$

In these agreements, Westerfield received $90 \%$ of the profits from fees billed to Florida clients, leaving her partners a meager $10 \%$ distribution. ${ }^{240}$ Each partner left Westerfield shortly after little to no work was completed, ultimately leading to the collapse of the firm. ${ }^{241}$ Following the collapse, Westerfield appointed an attorney to handle the clients whom already paid the flat fee, but refused to provide assistance or issue refunds of unearned fees after the appointed counsel discontinued their work. ${ }^{242}$

Westerfield's second through fourth counts of misconduct involved three different clients under substantially similar fact patterns. ${ }^{243}$ The clients, none of whom had prior relationships with Tope, met him through seminars or other events of that nature. ${ }^{244}$ These meetings led to Tope facilitating the execution of the flat fee representation agreements with Westerfield's firm. ${ }^{245}$ Westerfield charged each homeowner but never pursued a quiet title action or loan reduction as promised. ${ }^{246}$

Westerfield's misconduct consisted of violations of Professional Conduct Rules:

- 4-1.5(a): Charging and collecting a fee generated by employment obtained through prohibited solicitation.

- 4-1.16(d): Failing to refund an unearned fee.

- 4-5.5(a): Engaging in the unauthorized practice of law.

- 4-5.5(b)(1): Establishing an office for the practice of law in Florida despite not being licensed to practice in Florida.

- 4-7.18(a)(1): Improperly soliciting, directly through an agent, employment from a person with whom the lawyer has no prior relationship when a significant motive is the lawyer's pecuniary gain. ${ }^{247}$

237. $I d$.

238. Id.

239. Id.

240. Id.

241. Id.

242. In Counts II through IV, each client requested a refund of unearned fees. Westerfield provided only one client a partial refund. Id.

243. Id.

244. Id.

245. $I d$.

246. Id.

247. Id. at 220. 
Westerfield's received an eighteen-month suspension of her law license without automatic reinstatement. ${ }^{248}$ This sanction will be detailed later in this Article.

$$
B \text {. In re Fratini }{ }^{249}
$$

Pamela Fratini found herself in similar circumstances after affiliating herself with U.S. Legal Services Group (USLSG). USLSG is a California corporation that advertises various debt relief services nationwide through its website and direct mail solicitation. ${ }^{250}$

In this scheme, debtors were screened by non-lawyers who then facilitated the signing of retainer agreements that required a nonrefundable fee of $\$ 399$, an $18 \%$ of total debt at issue legal fee, and monthly payments toward escrow and legal fees over a four-year span. ${ }^{251}$ USLSG would only attempt to negotiate the client's debt once a designated sum had accumulated in escrow. ${ }^{252}$

Fratini received the signed retainer agreements, reviewed and filed them to ensure the debt settlement program was suitable for each individual debtor. ${ }^{253}$ The agreements did not provide for representation of the debtor if sued by the creditor, but instead offered a "Debt Defense" that was available after three additional payments. $^{254}$

Although Fratini did not supervise the initial meetings, nor any of the services rendered by the non-lawyer, she signed the agreements as "Approved by IN Attorney." 255 Fratini did not consult with every client whose file she reviewed, and neither did she discuss her limited role until after they signed the agreement. ${ }^{256}$ In total, Fratini was involved in 149 cases. $^{257}$

Fratini's misconduct consisted of violations of Professional Conduct Rules:

- 1.4(a)(1): Failure to promptly inform a client of circumstance (limited scope of employment) to which the client's informed consent is required.

- 1.4(a)(5): Failure to consult with client about any relevant limitation on the lawyer's conduct when the lawyer knows that the client expects assistance.

- 5.3(b) and Guideline 9.3: Failure to make reasonable efforts to

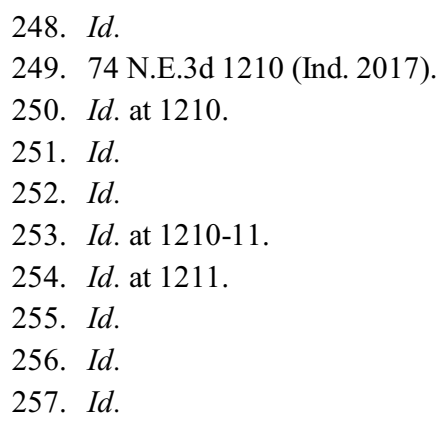


ensure that the conduct of a non-lawyer over whom the lawyer has direct supervisory authority is compatible with the professional obligations of the lawyer.

- 5.5(a): Assisting in the unauthorized practice of law.

- 8.4(a): Knowingly assisting another to violate the Rules of Professional Conduct (specifically charging and colleting an unreasonable fee and using an improper trade name). ${ }^{258}$

Westerfield and Fratini shared numerous common elements, including forming or joining interstate legal service groups, utilizing nonlawyer legal assistants to solicit, screen and execute the signing of representation agreements and fee agreements in violation of the Rules of Professional Conduct and participating in or assisting in the unauthorized practice of law. ${ }^{259}$ However, the most notable difference between the cases lies in their sanctions.

Fratini received a six months suspension without automatic reinstatement. ${ }^{260}$ This is distinguishable from the eighteen months suspension received by Westerfield for similar misconduct. ${ }^{261}$

In Westerfield, the court did not cite precedent for its sanction determination, but instead seemed to rely upon aggravating factors. The court first noted Westerfield's lengthy disciplinary history, including a private reprimand and a suspension for her failure to cooperate with a disciplinary investigation, which was converted the following year into an indefinite suspension without automatic reinstatement due to her continued noncooperation. ${ }^{262}$ Secondly, the court noted the hearing officer's findings that during her testimony, Westerfield was "disingenuous and evasive" about her relationship with non-lawyer assistant, Tope. ${ }^{263}$ Additionally, Westerfield attempted to distance herself from Tope's actions, despite the ample evidence that he was soliciting clients at her behest. ${ }^{264}$

The court also emphasized the amount of money Westerfield was receiving from her clients. In addition to the flat fees, the representation agreements required that the client would owe Westerfield a 50\% contingency fee of any reduction in mortgage principal, to be secured with a lien against the property. ${ }^{265}$ Lastly, the court stressed that Westerfield failed to acknowledge any wrongdoing and described the disciplinary proceedings as a "witch hunt."266 Four Justices

258. Id.

259. See generally id.; In re Westerfield, 64 N.E.3d 218 (Ind. 2016).

260. In re Fratini, 74 N.E.3d at 1211.

261. In re Westerfield, 64 N.E.3d at 220.

262. See generallyid.

263. Id. at 220 .

264. Id.

265. Id.

266. In an interview with the Indiana Lawyer, Westerfield's lack of remorse and arrogance is displayed in the following quote, "I also have a non-profit that I started in 2012 and hope to teach again through the non-profit. I live close to the beach. I love my life in Florida. And how many people that attended law school can say that?" Dave Stafford, Indiana attorney with failed Florida 
concurred on Westerfield's eighteen-month suspension. ${ }^{267}$ Justice Steven David dissented believing that a more severe discipline was warranted. ${ }^{268}$

The court took an entirely different approach in its analysis of Pamela Fratini's misconduct. This is likely due to Fratini agreeing to misconduct charges and sanction through a Conditional Agreement for Discipline. ${ }^{269}$ Rather than issuing a Per Curiam Opinion, the court ruled upon Fratini though an Order of Discipline. ${ }^{270}$ The court declined to specifically mention the presence of aggravating or mitigating factors, and instead relied heavily on precedent involving similar misconduct. ${ }^{271}$

The court first referred to In re Joyce, ${ }^{272}$ a published order suspending the lawyer for 180 days without automatic reinstatement for violation of rules 1.4(a)(2), 1.8(f), 5.4(a), 5.4(c), 5.5(a) and 7.3(e). ${ }^{273}$ John Joyce provided legal services to customers of United Financial Systems Corporation (UFSC), an insurance marketing agency that utilized non-lawyer sales representatives and provided estate planning services advertised to avoid probate. ${ }^{274}$ UFSC provided Joyce with templates that he used on clients during telephone conversations and other correspondence. ${ }^{275}$ Once he prepared the estate plan documents, Joyce sent them to UFSC where a sales representative assisted the clients in executing them while attempting to sell them insurance products. ${ }^{276}$ Joyce received a small portion of the total fees collected from the client's purchase of an estate plan. ${ }^{277}$

The court also cited In re Dilk, ${ }^{278}$ another published order suspending the lawyer for a period of not less than six months without automatic reinstatement for violation of Rules 1.4(a), 1.4(b), 1.8(f), 3.2, 5.4(a), 5.4(c), 5.5(a), 7.3(e), 8.4(d). ${ }^{279}$ Gary Dilk affiliated himself with Foreclosure Solutions, a for-profit Ohio LLC that referred approximately 2,675 cases to him at a standard rate of compensation of $\$ 125$ to $\$ 150$ per case. ${ }^{280}$ Dilk essentially acted as a license for hire that was willing to enter an appearance on behalf of clients in order to stall

firm calls ethics complaint against her a 'witch hunt', IND. LAw. (Nov. 2, 2016), https://www.theindianalawyer.com/articles/41883-indiana-attorney-with-failed-florida-firm-callsethics-complaint-against-her-a-witch-hunt [https://perma.cc/HLM5-V2DK].

267. In re Westerfield, 64 N.E. $3 \mathrm{~d}$ at 220.

268. Id.

269. In re Fratini, 74 N.E.3d 1210 (Ind. 2017).

270. $I d$.

271. See generally id.

272. 9 N.E.3d 142 (Ind. 2014).

273. Id. at 143 .

274. Id. at 142. John Joyce was also named a defendant in United Financial, in which the Court previously held UFSC engaged in the unauthorized practice of law. Id. at 143.

275. Id. at 142 .

276. Id. at $142-43$.

277. Id. at 143 .

278. 2 N.E.3d 1263 (Ind. 2014).

279. Id. at 1265 .

280. Id. at 1264 . 
foreclosure proceedings. ${ }^{281}$ The court emphasized that Dilk's misconduct was not isolated and that foreclosure defense referrals constituted nearly half of his entire practice. ${ }^{282}$ Most importantly, the court noted that it was unclear how many clients might have had the ability to save their homes had they engaged an attorney to provide proper, individualized legal advice. ${ }^{283}$

Fratini was akin to Joyce and Dilk in that she profited from providing limited services with little to no individualized attention to her clients, and neither did she properly inform the clients of her limited role. Unlike Westerfield, Fratini cooperated with the disciplinary process and accepted fault for her conduct as displayed in her court-approved conditional agreement. Thus, the court was more inclined to base its analysis and choice of a lesser sanction on similar precedent as opposed to compiling aggravating factors through a record such as prior disciplinary history, lack of cooperation, lack of remorse and overall evasiveness.

\section{In re Wall ${ }^{284}$}

Justin Wall received a surprisingly lesser sanction in comparison to the previous rent-a-license cases. Wall signed on first as an "associate" and later a "partner" with McCann Law Group d/b/a Consumer Attorney Services ("CAS"), ${ }^{285}$ a Florida corporation that offered clients services relating to bankruptcy, mortgage modification and foreclosure defense. ${ }^{286}$ Similar to USLSG, CAS advertised nationwide and employed non-lawyers to oversee client intake, along with the execution of representation agreements. ${ }^{287}$ These agreements contained an upfront nonrefundable fee and in some cases, ongoing monthly fees. ${ }^{288}$

Once a paralegal in Florida delegated Wall a case with a signed client agreement, he would perform a "welcome call" in which he would explain the "boots in the trenches" for CAS, providing discrete services and assisting clients through mortgage modifications or foreclosure defenses. ${ }^{289}$ Wall received fixed sums for select services, which made up only a small fraction of the total fee charged to clients by $\mathrm{CAS}^{290}$ Additionally, Wall received $\$ 25$ for every case assigned to other CAS attorneys in Indiana and a minimum wage 10-20 hours per week as "partner pay." 291

Wall's misconduct consisted of violations of Professional Conduct Rules:

281. $I d$.

282. Id. at 1266 .

283. Id.

284. 73 N.E.3d 170 (Ind. 2017).

285. Id. at 171-72.

286. Id. at 172 .

287. Id. at 171 .

288. Id. at 172 .

289. Id.

290. Id.

291. Id. 
- 1.5(e): A division of a fee between lawyers who are not in the same firm may be made only if: (1) the division is in proportion to the services performed by each lawyer or each lawyer assumes joint responsibility for the representation; (2) the client agrees to the arrangement, including the share each lawyer will receive, and the agreement is confirmed in writing; and (3) the total fee is reasonable.

- 5.5(a): Assisting in the unauthorized practice of law.

- 8.4(a): Knowingly assisting another to violate the RPC (specifically charging and colleting an unreasonable fee and using an improper trade name).

- 1.5(a): A lawyer shall not make an agreement for, charge, or collect an unreasonable fee or an unreasonable amount for expenses. ${ }^{292}$

The court cited numerous cases in Wall's Per Curiam opinion, the first being Consumer Attorney Services, P.A. v. State, ${ }^{293}$ where it affirmed the denial of summary judgment for CAS and its principal member in a suit brought by the Indiana Attorney General. ${ }^{294}$ CAS subcontracted with Indiana attorneys who then provided local services, their duties varying depending on whether they signed a "partnership," "associate," or "of counsel" agreement. ${ }^{295}$ After a slew of complaints from homeowners, the Indiana Attorney General investigated and later found that at no point between initial contact and retention did the majority of the clients have any contract with an Indiana-licensed attorney and the services they received were "perfunctory." 296 The State of Indiana then brought a civil suit against CAS and its attorneys, resulting in the court holding neither defendant was exempt from civil liability under various consumer protection statutes. ${ }^{297}$

The second case the court cited was In re Jackson. ${ }^{298}$ Eric Jackson was another CAS-associated attorney who agreed to a 120-day suspension with automatic reinstatement. ${ }^{299}$ Jackson provided services to CAS's Indiana loan modification and foreclosure clients, but non-lawyer employees performed all intake work and pleading drafting. ${ }^{300}$ Jackson was found in violation of Rules 1.4(a)(1), 1.4(a)(2), 1.4(a)(3), 1.4(a)(5), 1.4(b), 1.5(e), 5.3(b), 5.4(c), 5.5(a), 8.4(a), 8.4(c), and 8.4(d). ${ }^{301}$ The court did not find any facts in aggravation, and instead cited numerous facts in mitigation including his lack of prior disciplinary history, his cooperation with the disciplinary investigation and his remorse. ${ }^{302}$

292. Id. at 177; IND. Prof'L CONDUCt R. 1.5(e), 5.5(a), 8.4(a), 1.5(a) (2017).

293. 71 N.E.3d 362 (Ind. 2017).

294. Id. at $364,368$.

295. Id. at 363.

296. Id. at 364 .

297. Id.

298. 24 N.E.3d 419 (Ind. 2015).

299. Id. at 420.

300. Id. at 419 .

301. Id. at 420 .

302. Id. 
The court also relied heavily on State ex rel. Indiana State Bar Ass'n $v$. United Financial Systems Corp. ${ }^{303}$ when analyzing CAS's business model. In this case, it found more similarities than differences between CAS and the practices at issue in United Financial. The practices in United Financial mirrored those conducted by CAS in Wall, in that both business models "marginalized the attorney's role to such a degree as to cross the line of permissible practices." Further, the court referenced Dilk stating, "Without the involvement of Respondent, the [company] could not have provided the services they offered to homeowners. Selling the assistance of an attorney to defend a foreclosure action was a necessary part of their business model." 305

In deciding Justin Wall's sanction, the court closely followed its decision in Jackson by shifting its focus to the presence of mitigating factors. Both Jackson and Wall showed remorse for their respective conduct, cooperated with the disciplinary investigation and shared a lack of disciplinary history, but the court still imposed a lighter sanction on Wall. ${ }^{306}$

The main distinction between Wall and prior rent-a-license cases is the lack of actual harm in conjunction with the misconduct playing a minute role in the attorney's practice. The emphasis on these mitigating factors is supported by Dilk, where the court extensively emphasized that the lawyer affected close to 4,000 clients and received approximately $\$ 600,000$ from them over a five-year period, earning him a much harsher penalty. ${ }^{307}$ Additionally, although not cited as a specific aggravating factor, Westerfield, who received the heaviest sentence, did actually harm a handful of clients.

The court in Wall concluded after examining the totality of the factors that, "While no one factor necessarily is dispositive, the evidence in its totality leads us to conclude the Respondent and CAS were not 'in the same firm." "'308 Wall's "associate" agreement expressly identified and treated him as an independent contractor. ${ }^{309}$ He maintained his own law firm (Wall Legal Service) throughout his relationship with CAS, using his own firm name and letterhead in pleadings and correspondence sent to parties in connection with CAS cases. ${ }^{310}$

Finally, the court directed its attention to the nature and motive behind Wall's misconduct, stating that it could not be surmised as dishonest or deceitful in the manner contemplated by Rule $8.4(\mathrm{c}) .^{311}$ While ill-advised, his actions appeared "well intentioned and done without selfish motive." ${ }^{12} \mathrm{He}$ did not have the intent to deceive or simply to generate quick fees with little work at the expense of his

303. 926 N.E.2d 8 (Ind. 2010).

304. Id. at 15 .

305. In re Wall, 73 N.E.3d 170, 176 (Ind. 2017).

306. Id. at 177.

307. In re Dilk, 2 N.E.3d 1263, 1266 (Ind. 2014).

308. In re Wall, 73 N.E.3d at 173-74.

309. Id. at 173 .

310. Id.

311. Id. at 176 .

312. Id. at 171. 
clients, nor was there evidence of “person's being misled by Respondent's identification as a 'partner' on CAS's website."'313

In sum, the court has adopted a more flexible approach in determining the level of misconduct present in rent-a-license cases. This approach focuses less on precedent when determining the appropriate sanction and more on the lawyer's conduct during the disciplinary process, reprehensibility, and the extent of harm arising from the misconduct.

\section{DISCIPLINE ORDERS OF PARTICULAR INTEREST}

Two lawyer license sanctions that were disposed by an Order of Discipline rather than a Per Curiam Order are worth commentary. Both involved an elected prosecuting attorney and their respective conflicts of interest.

\section{A. In re Keith Henderson ${ }^{314}$}

Keith Henderson is the elected prosecuting attorney in Floyd County Indiana, and chairman of the Indiana Prosecuting Attorneys Council Ethics Committee. ${ }^{315}$ He presided over the prosecution of former Indiana State Police officer David Camm who was charged with murdering his wife and two minor children. ${ }^{316}$ From 2000 to 2013, Camm faced three prosecutions for the murders (hereinafter referred to as Camm I, ${ }^{317} \mathrm{Camm} \mathrm{II,},{ }^{318}$ and Camm III. Camm was convicted twice of the murders and both times the convictions were reversed (Camm I and Camm II). On the third trial he was acquitted. ${ }^{319}$ Henderson prosecuted the second trial and initiated the third trial. ${ }^{320} \mathrm{He}$ was removed as the State's counsel from the third trial upon a determination of conflict of interest. ${ }^{321}$

Shortly after the jury verdict of guilty in Camm II, Henderson entered into an agreement with a literary agent in order to author and publish a book about the Camm case. ${ }^{322}$ Meanwhile, he continued to represent the State in post-trial proceedings and assisted the Attorney General in the Camm II appeal. ${ }^{323}$ Also,

313. Id. at 176 .

314. 78 N.E.3d 1092 (Ind. 2017).

315. Floyd County Prosecutor - Keith A. Henderson, IN.gOv https://www.in.gov/ipac/ 2962.htm [https://perma.cc/6JGG-9MKS] (last visited June 21, 2018).

316. Missy Wilson, Suspended Justice, IDS, http://www.idsdavidcamm.com/ [https://perma.cc/4BVH-MJU8] (last visited June 21, 2018).

317. Camm v. State, 812 N.E.2d 1127 (Ind. Ct. App.), trans. denied, 822 N.E. 2d 980 (Ind. 2004).

318. Camm v. State, 908 N.E.2d 215 (Ind. 2009).

319. Wilson, supra note 316.

320. In re Henderson, 78 N.E.3d 1092 (Ind. 2017).

321. The defense raised a Motion to Disqualify Henderson as State's counsel after it discovered his conflict of interest. Camm v. State, 957 N.E.2d 205 (Ind. Ct. App. 2011), trans. denied, 963 N.E.2d 1120 (Ind. 2012).

322. In re Henderson, 78 N.E.3d at 1093.

323. Id. 
during this post-trial period, he enhanced his attempt at personal gain by entering a publishing agreement with a publisher. ${ }^{324}$

When the reversal of conviction in Camm II was decided, Henderson communicated to the literary agent that "this is now a bigger story." ${ }^{, 25} \mathrm{He}$ also asked the agent to see if a publishing time frame could be "pushed back." ${ }^{326} \mathrm{He}$ also asked the agent "to push for something more out of the contract."

After these communications, Henderson refiled the murder charges, which set the stage for Camm III and for the interlocutory appeal. ${ }^{328}$ Henderson's actions led to the Disciplinary Commission alleging a conflict of interest and charging him with violations of Professional Conduct Rule 1.7(a)(2), ${ }^{329} 1.8(\mathrm{~d}),{ }^{330}$ and $8.4(\mathrm{~d})^{331}$ in Count 1 (a second Count of misconduct is discussed later in this Article). Clearly, Henderson had a personal financial stake in the outcome of the case. When in position to decide whether to bring murder charges for a third time against Camm, his mindset was to "push for something more out of the contract." ${ }^{332}$ Comment 1 to Professional Conduct Rule 3.8 $8^{333}$ advises that a

324. Id.

325. Id.

326. Id.

327. Id.

328. Id.

329. See Ind. Prof'L Conduct R. 1.7(a)(2) (2017):

Conflict of Interest: Current Clients

(a) Except as provided in paragraph (b), a lawyer shall not represent a client if the representation involves a concurrent conflict of interest. A concurrent conflict of interest exists if: ...

(2) there is a significant risk that the representation of one or more clients will be materially limited by the lawyer's responsibilities to another client, a former client or a third person or by a personal interest of the lawyer.

330. See Ind. Prof'l Conduct R. 1.8(d):

\section{Conflict of Interest: Current Clients: Specific Rules}

(d) Prior to the conclusion of representation of a client, a lawyer shall not make or negotiate an agreement giving the lawyer literary or media rights to a portrayal or account based in substantial part on information relating to the representation.

331. See Ind. Prof'L CONDUCT R. 8.4(d):

Misconduct

It is professional misconduct for a lawyer to:

(d) engage in conduct that is prejudicial to the administration of justice[.]

332. In re Henderson, 78 N.E.3d at 1093.

333. See Ind. Prof'l Conduct R. 3.8:

Special Responsibilities of a Prosecutor

The prosecutor in a criminal case shall:

(a) refrain from prosecuting a charge that the prosecutor knows is not 
prosecutor is not merely an advocate, but also a minister of justice. The Comment also recognizes that a knowing disregard of this obligation or abuse of prosecutorial discretion could be a violation of Professional Conduct Rule 8.4. ${ }^{334}$

supported by probable cause;

(b) make reasonable efforts to assure that the accused has been advised of the right to, and the procedure for obtaining, counsel and has been given reasonable opportunity to obtain counsel;

(c) not seek to obtain from an unrepresented accused a waiver of important pretrial rights, such as the right to a preliminary hearing;

(d) make timely disclosure to the defense of all evidence or information known to the prosecutor that tends to negate the guilt of the accused or mitigates the offense, and, in connection with sentencing, disclose to the defense and to the tribunal all unprivileged mitigating information known to the prosecutor, except when the prosecutor is relieved of this responsibility by a protective order of the tribunal;

(e) not subpoena a lawyer in a grand jury or other criminal proceeding to present evidence about a past or present client unless the prosecutor reasonably believes:

(1) the information sought is not protected from disclosure by any applicable privilege;

(2) the evidence sought is essential to the successful completion of an ongoing investigation or prosecution; and

(3) there is no other feasible alternative to obtain the information;

(f) except for statements that are necessary to inform the public of the nature and extent of the prosecutor's action and that serve a legitimate law enforcement purpose, refrain from making extrajudicial comments that have a substantial likelihood of heightening public condemnation of the accused and exercise reasonable care to prevent investigators, law enforcement personnel, employees or other persons assisting or associated with the prosecutor in a criminal case from making an extrajudicial statement that the prosecutor would be prohibited from making under Rule 3.6 or this Rule.

334. Id. Comment [1]:

A prosecutor has the responsibility of a minister of justice and not simply that of an advocate. This responsibility carries with it specific obligations to see that the defendant is accorded procedural justice and that guilt is decided upon the basis of sufficient evidence. Applicable law may require other measures by the prosecutor and knowing disregard of those obligations or a systematic abuse of prosecutorial discretion could 
The court noted that Henderson's misconduct was serious and had an adverse effect on the administration of justice. ${ }^{335}$ However, it also weighed the mitigating facts that the misconduct occurred in a single case, as well as his long and distinguished career. ${ }^{336}$ The supreme court found that Henderson violated each of the rules charged in Count 1 and imposed a public reprimand. ${ }^{337}$

The Disciplinary Commission charged Henderson with a second count of misconduct arising from partial payment of his defense attorney's fees related to Count $1 .{ }^{338}$ Henderson sought payment of his attorney fees from his local county funding authority. ${ }^{339}$ Personal misconduct is outside his scope of employment but the local funding authority can elect to pay for this personal expense. ${ }^{340}$ The Commission did not allege that Henderson should not have had personal expenses paid by his county. Rather, the Commission alleged that he was deceitful in his method of submitting his payment claims to the County Auditor. ${ }^{341}$ He listed the expenses as incurred in the Camm litigation when in fact they were incurred in his personal defense of the professional misconduct litigation regarding his own law license. ${ }^{342}$ The Commission charged Henderson with engaging in dishonest, fraudulent, deceitful or misrepresented conduct (Professional Conduct Rule 8.4(c)) and engaging in conduct prejudicial to the administration of justice (Professional Conduct Rule 8.4(d)). ${ }^{343}$ The court ruled that the Commission failed to prove Count 2 by clear and convincing evidence. ${ }^{344}$

\section{B. In re Carl Brizzi ${ }^{345}$}

A second Order of Discipline involved conflict of interest by former Marion County Prosecuting Attorney Carl Brizzi. ${ }^{346}$ Brizzi was previously sanctioned in 2012 for unrelated discipline. ${ }^{347}$ In this current reported matter, Brizzi engaged in a conflict of interest with criminal defense attorney Paul Page. ${ }^{348}$ Together, they were involved in a joint real estate venture protected under a limited liability corporation. ${ }^{349}$

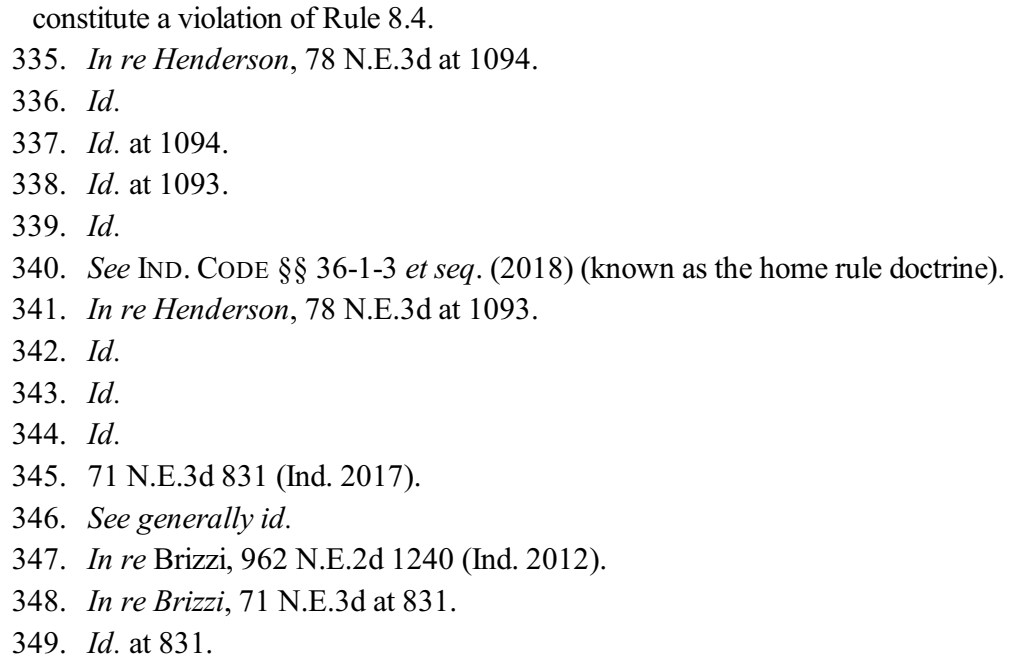


Page represented a client named Mobareck on drug charges in Marion County. ${ }^{350}$ The deputy prosecutors assigned to the Mobarecki case reached a plea deal that included a cash forfeiture of $\$ 17,550$ seized during the arrest and a plea to a Class $\mathrm{C}$ felony offense. ${ }^{351}$ Page then went directly to Brizzi and renegotiated the case to a class D felony and a return of all cash to Mobarecki. ${ }^{352}$ Brizzi's intervention into the negotiation was not a regular procedure within the Prosecutor's office and was found to be "highly unusual.",353

Brizzi was found in violation of Professional Conduct Rule 1.7(a)(2) for having a conflict of interest with Page. ${ }^{354}$ Specifically, it found that there was a significant risk that Brizzi's representation of the State in the criminal prosecution was materially limited by Brizzi's own personal interest in his business relationship with Page. ${ }^{355}$ With his prior discipline serving as an aggravator, the court imposed a thirty-day license suspension with automatic reinstatement. ${ }^{356}$

\section{CONCLUSION}

The Indiana Supreme Court was quite busy with thirteen Per Curiam opinions for lawyer discipline during this reporting period. Several recurring themes were present in the discipline matters.

A common aggravating factor in many of the cases was the failure of the respondent lawyer to participate in the discipline process. Also, the court took a hard stance against several lawyers whose misconduct rested upon dishonesty and deceit. The court also addressed a recurring problem in three independent matters where the lawyers engaged in what has become known as license rental schemes which enable non-lawyers or unlicensed foreign jurisdiction lawyers to practice law in violation of law license acquisition standards. Also, the court independently sanctioned both a current and a former elected prosecuting attorney for engaging in business transactions that conflicted with their interests in representing the State of Indiana in criminal matters.

Lastly, the court might have created a new "heat of trial" exception for impassioned speech in a lawyer's closing argument that otherwise would be a violation of professional conduct rules. In asserting this possible exception, the court found no misconduct for the respondent lawyer, but still sternly reprimanded her in print for her ethically challenged comments to juries resulting in a no misconduct public reprimand.

350. $I d$.

351. Id.

352. Id. at 831-32.

353. Id. at 832 .

354. Id.

355. Id.

356. Id. 